\title{
FAKTOR-FAKTOR PENYEBAB KEMUNCULAN PRASANGKA SOSIAL (SOCIAL PREJUDICE) PADA PELAJAR
}

\author{
Oleh: Dede Rahmat Hidayat
}

\begin{abstract}
This study aims to investigate of the factors in the emergence of social prejudice student groups. The subjects of this study were student grade junior high school VIII.1 232 Jakarta, consisting of 38 students. They are a group of people on a small scale that represents some ethnic elements. The sampling technique is done by using the technique of sampling convinience. Measuring tool used is a semantic differential scale is an instrument to measure the response of the aspects of affective. The results showed that social prejudices on the subject is at the level of medium and low. In addition, the student social prejudice caused more by prejudices that are more personal and social nature. The emergence of prejudice is caused by cultural differences and the social distance between different ethnic groups.
\end{abstract}

Key Words: Student, social prejudice, social conflict.

\section{PENDAHULUAN}

Indonesia adalah sebuah negara dengan tingkat keragaman yang tinggi. Dengan demikian Indonesia secara alamiah adalah negara sangat berbhineka, tidak hanya dari etnisitas tetapi juga budaya secara umum. Dengan demikian banyaknya perbedaan akan memberikan dampakdampak, baik secara positif maupun negatif. Dampak positif tentunya memberikan keuntungan berupa kekayaan budaya yang luar biasa, tetapi sisi lain memberikan dampak negatif berupa adanya prasangka sosial. Jarak sosial yang jauh dan pemahaman yang rendah terhadap warga dari etnis yang berbeda akan membuat kemunculan konflik menjadi mudah terjadi. Karena itu, adanya cara untuk menjadikan perbedaan menjadi suatu kekuatan merupakan hal yang sangat penting untuk dapat dikembangkan di Indonesia.

Pada masa Orde Baru, keragaman yang ada ditekan, di mana perbedaan ini dianggap tidak ada, bentuk yang tampak adalah penyeragaman dalam berbagai hal. Penyeragaman ini dilakukan dengan pemaksaan, termasuk dalam bentuk kekerasan. Pada awal 1997 media massa memberitakan tentang kekerasan komunal yang dilakukan oleh suku Dayak terhadap suku Madura di Kalimantan Barat. Peristiwa itu berujung pada tewasnya ratusan orang Madura dan puluhan ribu lagi harus mengungsi keluar dari Kalimantan Barat. Selanjutnya, kita tahu

\footnotetext{
* Dosen Jurusan Bimbingan Konseling, Fakultas Ilmu Pendidikan Universitas Negeri Jakarta
} 
$42 \quad \begin{aligned} & \text { JURNAL ILMIAH MIMBAR DEMOKRASI } \\ & \text { VOLUME 12, NOMOR 2, APRIL } 2013\end{aligned}$

bahwa peristiwa itu hanyalah permulaan dari rentetan panjang kekerasan komunal yang dibangun melalui prasangka etnis, gender, ras, kelas, dan agama di Indonesia pada momen-momen paling rawan dalam perpindahan rezim Orde Baru ke Orde Reformasi.

Salah satu penelitian (Varshney, Panggabean, dan Tadjoeddin 2004) menampilkan data yang menunjukkan banyaknya peristiwa kekerasan massal dan jumlah orang yang tewas dalam peristiwa sepanjang tahun 1997 sampai 2003. Pada tahun 1997, lebih dari seribu orang tewas secara mengenaskan dan jumlahnya terus meningkat sampai tahun 1999. Jika jumlah orang yang tewas selama tiga tahun tersebut digabungkan, angkanya mencapai 6.047 jiwa dari 1.209 peristiwa kekerasan massal. Sampai tahun 2001, berbagai kekerasan massal terus berlangsung meskipun jumlah korban tewas mulai menurun. Baru sejak tahun 2002 jumlah kekerasan massal dan korban tewas menurun cukup drastis dibandingkan tahun-tahun sebelumnya.

Salah satu komunitas terjadinya kekerasan adalah sekolah. Untuk Jakarta situasinya lebih khusus, sebagai melting pot etnis, agama, dan budaya telah lama menjadi tujuan migrasi, sehingga tidak aneh berbagai etnis terdapat di sini. Di antara generasi yang datang adalah anak usia sekolah, baik dari generasi kedua maupun ketiga. Sekolah menjadi melting pot budaya, di mana dalam sekolah kumpulan etnis dipersatukan dalam kelas serta berbagai aktivitasnya. Sebagaiman catatan pada pendahuluan berbagai bentuk kekerasan yang melibatkan pelajar, telah lama terjadi dan banyak korban karenanya. Salah satu kemunculan kekerasan dalam pendidikan di sekolah adalah prasangka sosial antara para pelajar tersebut. Kemunculan prasangka dapat menjadi cikal bakal kemunculan kekerasan. Kondisi ini tidak hanya terjadi di masyarakat tetapi juga di tingkat sekolah, khususnya Sekolah Menengah Pertama (SMP).

\section{Rumusan Masalah}

Berdasarkan beberapa masalah di atas maka rumusan penelitian ini adalah,

“Apa faktor-faktor dalam sikap yang menyebabkan kemunculan prasangka sosial?

\section{Tujuan Penelitian}

Penelitian ini memiliki tujuan sebagai berikut :

1. Mendapatkan data awal mengenai faktor-faktor kemunculan prasangka sosial di sekolah terutama tingkat SMP

2. Menyusun sebuah urutan mengenai bentuk dari prasangka sosial yang dimiliki oleh para siswa di SMP. 
3. Menjadikan dasar bagi penyusunan model pembelajaran yang dapat mereduksi prasangka sosial di sekolah.

\section{Manfaat Penelitian}

Beberapa manfaat yang dapat diperoleh dari penelitian ini adalah sebagai berikut :

1. Memberikan informasi mengenai keberadaan dan bentuk dari prasangka sosial yang berada di sekolah, karena keberadaannya relatif laten yang seringkali kurang terlalu dipedulikan. Sementara yang menjadi isu utama adalah bentuk manifestasi dari prasangka sosial, berupa kekerasan dan diskriminasi. Dengan demikian adanya informasi yang dapat mengungkap akar kekerasan ini akan memberikan sumbangan bagi langkah ke depan guna melakukan pencegahan dan tindakan yang tepat.

2. Data yang diperoleh dari penelitian ini memberikan dasar bagi penyusunan sebuah bentuk intervensi dalam pembelajaran yang dapat mereduksi prasangka.

\section{DASAR TEORI DAN PENELITIAN}

\section{YANG RELEVAN}

\section{Dasar Teori}

1. Prasangka sosial

Kata prasangka dalam bahasa Inggrisnya prejudice, berasal dari bahasa
Latin praejudicium, yang memiliki banyak arti. Allport (1954) menjelaskan tiga tahapan perubahan makna kata prejudice, yaitu :

a. Di awal, praejudicium berarti sebuah preseden, keputusan yang didasarkan kepada pengalaman dan keputusan masa lalu.

b. Selanjutnya dalam istilah bahasa Inggris, memerlukan makna dari sebuah keputusan yang dibentuk oleh dasar penelitian dan pertimbangan terhadap fakta yang prematur dan keputusan yang terburu-buru.

c. Akhirnya, istilah prasangka adalah kondisi emosional yang dirasakan sebagai akibat kesukaan atau ketidaksukaan bahwa temannya merupakan yang utama atau sebaliknya keputusan yang tidak mendukung

Kata prasangka dalam New England Dictionary meliputi prasangka positif (positive prejudice) ataupun juga prasangka negatif (negative prejudice) diterjemahkan dengan: sebuah perasaan menyenangkan ataupun tidak menyenangkan terhadap benda atau orang yang tidak didasarkan kepada pengalaman yang aktual.

Allport (1954) mendefinisikan prasangka sebagai, sikap berumusuhan atau memalingkan muka terhadap orang 
$44 \quad \begin{aligned} & \text { JURNAL ILMIAH MIMBAR DEMOKRASI } \\ & \text { VOLUME 12, NOMOR 2, APRIL } 2013\end{aligned}$

orang yang memiliki kelompok, secara sederhana disebabkan karena dia memiliki kelompok, maka mengira bahwa memiliki kualitas yang dituju yang dianggap terhadap kelompok.

Dalam kamus ilmu sosial (Dictionary of the Social Sciences, 1964) dan Handbook of Social Psychology (1954) prasangka didefinisikan sebagai sikap yang tidak menyukai etnik tertentu.

Prasangka sosial membuat seseorang atau sekelompok orang mengingkari adanya kesamaan dan persamaan hak (Koeswara, 1988). Menurut Allport (1954) dengan prasangka, seseorang atau sekelompok orang menganggap buruk atau memandang negatif orang lain secara tidak rasional. Prasangka dianggap sebagai suatu predisposisi untuk mempersepsi, berpikir, merasa dan bertindak dengan cara-cara yang menentang atau menjauhi dan bukan menyokong atau mendekati orang lain. Dengan demikian prasangka menyangkut kecenderungan untuk menjauhi orang dengan mengambil jarak dan tidak berhubungan erat dengan mereka serta kecenderungan untuk merugikan dan tidak membantu mereka (Newcomb, 1985).

\section{Penyebab prasangka sosial}

Berbagai pandangan dan konsep teoritis yang menyebabkan seseorang memiliki prasangka sosial adalah sebagai berikut : a. Allport (1954) dan Tajfel (dalam Turner \& Giles, 1985) memandang munculnya prasangka karena adanya proses kategorisasi dalam diri individu. Ditegaskan pula bahwa kategorisasi sosial merupakan basis psikologis dari munculnya prasangka. Kategorisasi tersebut mencakup etnisitas dan kecenderungan menjaga jarak sosial dengan orang-orang yang dianggap outgroup.

b. Selain itu prasangka terkait dengan berbagai jenis kepribadian yang antara lain; otoriter, konsep diri, self-esteem dan orientasi dominasi sosial. Dalam salah satu teorinya, Adorno (dalam Faturrohman, 1993) menyatakan bahwa, prasangka berhubungan dengan pola kepribadian seseorang. Menurut Adorno individu yang memiliki prasangka yang tinggi biasanya memiliki kepribadian otoriterisme. Hubungan positif antara self-esteem dan identitas sosial yang dengan prasangka, dikemukakan oleh Fien \& Spencer (1995) bahwa ancaman terhadap identitas sosial dan self-esteem mendorong untuk mengembangkan penilaian prasangka terhadap orang lain. Orientasi dominasi sosial (social dominance orientation) adalah seseorang yang berkeinginan untuk memiliki dominasi pada ingroup-nya dan menjadi 
superior pada outgroup. Individu dengan dominasi sosial yang tinggi cenderung bersikap negatif terhadap beberapa kelompok yang marginal seperti etnis minoritas, feminis, kelompok homoseksual (Whitley, 1999).

c. Faktor lain berperan dalam terjadinya prasangka adalah hasil proses belajar (social learning theory). Menurut teori ini prasangka pada dasarnya dipelajari oleh individu dari perilaku individu lain di sekitarnya dan dari normanorma sosial yang terdapat di dalam masyarakat kebudayaannya. Berbagai penelitian yang dilakukan di Amerika Serikat menunjukkan bahwa orangorang Amerika yang berasal dari bagian selatan lebih berprasangka dibandingkan dengan daerah-daerah lain di Amerika Serikat, karena sejarah dan kondisi sosial yang diwariskan pada mereka penuh dengan kekerasan dan prasangka rasial. Kelas pekerja lebih berprasangka daripada kelas menengah, karena lingkungan yang miskin dan kurang berpendidikan membuat mereka lebih berprasangka. Selain itu orang tua kulit putih lebih berprasangka daripada orang muda kulit putih, karena mereka pernah hidup dalam zaman yang diskriminatif dan segregatif (Sears dkk, 1991). d. Hal lain yang mempengaruhi prasangka adalah keinginan untuk berkompetisi terutama untuk mendapatkan sumber daya yang sangat berharga tetapi pada kenyataannya persediaannya hanya dalam jumlah yang sangat terbatas, misalnya pekerjaan, daerah kekuasaan atau jabatan. Menurut teori realistic group conflict, kompetisi akan menimbulkan permusuhan serta penilaian yang negatif terhadap kelompok lain (outgroup).

e. Teori norma kelompok yang dikemukakan oleh Sherif dan Sherif (dalam Crandall dkk, 2002) menggambarkan tentang perkembangan prasangka yang dikaitkan dengan norma sosial kelompok dan adanya tekanan agar individu dapat conform terhadap norma kelompok tersebut. Menurut teori ini, sikap, nilai-nilai, keyakinan dan prasangka merupakan bagian dari proses sosialisasi: "the attitude of prejudice is a product of group membership" (Sherif; dalam Crandall dkk, 2002). Menurut Sherif (dalam Crandall dkk, 2002) sikap, nilai-nilai dan prasangka bukan merupakan hasil dari pilihan-pilihan individu yang diperoleh selama hidupnya. Hal tersebut merupakan hasil kontak dengan anggota dari kelompok lain, 
$46 \quad \mid \begin{aligned} & \text { JURNAL ILMIAH MIMBAR DEMOKRASI } \\ & \text { VOLUME 12, NOMOR 2, APRIL } 2013\end{aligned}$

yang kemudian distandardisasikan lalu diinternalisasikan menjadi nilai-nilai kelompoknya. Kepatuhan seseorang pada nilai-nilai in-groupnya akan mengarahkan pada munculnya prasangka.

\section{Pengukuran Prasangka Sosial}

Prasangka seseorang dapat dinilai dengan melihat dan memparhatikan caracara orang berhubung antara satu sama lain. Untuk kepentingan ilmiah, prasangka dapat diketahui melalui metode kajian yang sistematis. Salah satu metode kajian itu adalah alat kajian yang berfungsi mengukur prasangka.

Sikap etnik dapat diukur dengan menggunakan kaedah pengukuran sikap Semantic Differential Scale yang diperkenalkan oleh Osgood, Tannenbaum \& Suci (1957). Semantic diffenretial mengukur reaksi orang terhadap rangsangan dalam item-item pemeringkatan berasaskan skala dwikutub yang didefinisikan dengan menggunakan kata sifat pada dua hujung. Ini merupakan prosedur menaksir respons secara perasaan (afektif). Item-item yang dimasukkan dalam skala ini biasanya mengandungi tiga dimensi iaitu penilaian, kekuatan dan aktiviti (Heise 1970).

Sifat-sifat itu diambil mengikut kesesuaian budaya masyarakat setempat dan hal-hal yang selalu dinilai oleh individu terhadap individu lain. Para subjek boleh menilai bangsa apa saja yang mereka inginkan termasuk bangsanya sendiri dengan membulatkan atau menggariskan bangsa yang dinilai. Selepas itu subjek akan mula menilai dengan menandakan satu saja jawaban pada garisan yang telah dibuat untuk kesemua sifat-sifat stereotaip yang telah diberikan sebagai rangsangan.

\section{Penelitian yang Relevan}

Sarlito Wirawan Sarwono (2006) menyatakan bahwa prasangka banyak dilakukan di bidang komunikasi, terutama tentang prasangka yang terkandung di dalam cara media massa meliput peristiwa konflik sosial di akhir Orde Baru. Untuk menyebut beberapa contoh misalnya yang dilakukan, Sudibyo, Hamad, dan Qodari (2001) meneliti prasangka agama di media massa terkemuka di Indonesia; Nadapdap, dkk. (2003) meneliti prasangka rasial di media massa; dan Eriyanto (2004) meneliti prasangka etnis di media massa dalam kerusuhan di Sampit Kalimantan Tengah.

Penelitian prasangka di media massa tersebut banyak memanfaatkan teori dan metode analisis wacana. Teori dan metode ini sangat fungsional dan interdisiplin sehingga cukup efektif untuk dikombinasi dengan teori lain. Kajian wanita, misalnya, 
yang banyak mendasarkan diri pada teori feminis juga banyak memanfaatkan teori dan metode tersebut. Dalam hal ini, Kasiyan (2008) meneliti iklan di majalah yang cenderung menampilkan perempuan sebagai obyek seksual dan sosok domestik. Prasangka gender seperti ini ternyata dapat pula terkait dengan identitas kebudayaan yang lain, misalnya ras. Penelitian Aquarini (2003) dan Vissia Ita (2007) memperlihatkan betapa dominannya standar ras Eropa dalam representasi iklan tentang kecantikan perempuan di Indonesia.

\section{METODE PENELITIAN}

Penelitian ini merupakan jenis penelitian eksploratif yang berusaha untuk mengumpulkan berbagai faktor yang berpengaruh kepada pembentukan prasangka sosial.

\section{Populasi, Sampel dan Teknik Sampling}

Populasi penelitian adalah para pelajar di SMPN 232 Jakarta. Dari seluruh populasi yang dipilih sejumlah sampel yang berada di kelas IX.1, pemilihannya sampel dengan menggunakan convinience sampling.

\section{HASIL PENELITIAN DAN \\ PEMBAHASAN}

\section{A. Hasil Penelitian}

Berdasarkan hasil pengukuran dengan menggunakan semantik differensial didapatkan bahwa sikap prasangka berdasarkan kesukuan secara umum dapat dilihat pada tabel 1 .

\section{Analisis}

a. Taraf Prasangka

Berdasarkan pengukuran dengan menggunakan semantik differensial di atas, hasilnya menunjukan bahwa: Untuk sifat pribadi terdapat prasangka yang berada pada kategori tinggi sejumlah 1 orang (sikap etnis Jawa terhadap etnis Betawi), 20 orang berada dalam kategori sedang, sedangkan 17 berada dalam kategori rendah. Sementara untuk sifat sosial tingkat prasangka berada dalam taraf sedang dan rendah dengan jumlah yang berimbang, yaitu masing-masing 19 orang. Untuk sifat kerja, prasangka yang muncul sebagian besar berada pada taraf rendah sebanya 24 orang dan hanya 14 orang berada pada taraf rendah. 
$48 \quad \mid \begin{aligned} & \text { JURNAL ILMIAH MIMBAR DEMOKRASI } \\ & \text { VOLUME 12, NOMOR 2, APRIL } 2013\end{aligned}$

Tabel 1. Hasil Pengukuran Prasangka Sosial

\begin{tabular}{|c|c|c|c|c|c|c|c|c|c|c|}
\hline \multirow{2}{*}{ No. } & \multirow{2}{*}{ Suku } & \multirow{2}{*}{$\begin{array}{l}\text { Obyek } \\
\text { Sikap }\end{array}$} & \multicolumn{2}{|c|}{ Sifat Pribadi } & \multicolumn{2}{|c|}{ Sifat Sosial } & \multicolumn{2}{|c|}{ Sifat Kerja } & \multicolumn{2}{|c|}{ Sifat Etnis } \\
\hline & & & Skor & Kategori & Skor & Kategori & Skor & Kategori & Skor & Kategori \\
\hline 1 & MINANG & BATAK & 16 & $S$ & 22 & $S$ & 14 & $R$ & 52 & $S$ \\
\hline 2 & MINANG & BETAWI & 20 & $S$ & 19 & $S$ & 14 & $\mathrm{R}$ & 53 & $S$ \\
\hline 3 & JAWA & BETAWI & 22 & $\mathrm{~T}$ & 21 & $S$ & 17 & $\mathrm{R}$ & 60 & $S$ \\
\hline 4 & MINANG & BETAWI & 19 & $S$ & 22 & $S$ & 17 & $S$ & 58 & $S$ \\
\hline 5 & BETAWI & SUNDA & 17 & $S$ & 18 & $S$ & 17 & $S$ & 52 & $S$ \\
\hline 6 & MINANG & BETAWI & 17 & $S$ & 16 & $\mathrm{R}$ & 17 & $S$ & 50 & $S$ \\
\hline 7 & JAWA & BETAWI & 20 & $S$ & 21 & $S$ & 18 & $S$ & 59 & $S$ \\
\hline 8 & JAWA & SUNDA & 14 & $S$ & 18 & $S$ & 15 & $R$ & 47 & $S$ \\
\hline 9 & $\begin{array}{l}\text { JAWA - } \\
\text { MINANG }\end{array}$ & SUNDA & 16 & $S$ & 18 & $S$ & 17 & $S$ & 51 & S \\
\hline 10 & JAWA & BETAWI & 20 & $S$ & 21 & $S$ & 22 & $S$ & 63 & $S$ \\
\hline 11 & JAWA & SUNDA & 13 & $R$ & 23 & $S$ & 16 & $R$ & 52 & $S$ \\
\hline 12 & JAWA & BETAWI & 20 & $S$ & 21 & $S$ & 21 & $S$ & 62 & $S$ \\
\hline 13 & JAWA & BETAWI & 17 & $S$ & 21 & $S$ & 16 & $R$ & 54 & $S$ \\
\hline 14 & BATAK & JAWA & 17 & $S$ & 15 & $R$ & 21 & $S$ & 53 & $S$ \\
\hline 15 & JAWA & BETAWI & 19 & $S$ & 20 & $S$ & 19 & $S$ & 58 & $S$ \\
\hline 16 & JAWA & BATAK & 20 & $S$ & 23 & $S$ & 18 & $S$ & 61 & $S$ \\
\hline 17 & SUNDA & BETAWI & 17 & $S$ & 18 & $S$ & 11 & $R$ & 46 & $S$ \\
\hline 18 & JAWA & BALI & 7 & $\mathrm{R}$ & 8 & $\mathrm{R}$ & 12 & $R$ & 27 & $\mathrm{R}$ \\
\hline 19 & JAWA & CINA & 16 & $S$ & 20 & $S$ & 9 & $R$ & 45 & $R$ \\
\hline 20 & JAWA & BATAK & 18 & $S$ & 18 & $S$ & 9 & $R$ & 45 & $R$ \\
\hline 21 & BETAWI & SULAWESI & 12 & $R$ & 14 & $R$ & 19 & $S$ & 45 & $\mathrm{R}$ \\
\hline 22 & JAWA & SUNDA & 12 & $R$ & 14 & $\mathrm{R}$ & 19 & $S$ & 45 & $\mathrm{R}$ \\
\hline 23 & BATAK & BALI & 10 & $R$ & 14 & $\mathrm{R}$ & 11 & $R$ & 35 & $\mathrm{R}$ \\
\hline 24 & BETAWI & USA & 10 & $R$ & 20 & $S$ & 15 & $R$ & 45 & $\mathrm{R}$ \\
\hline 25 & JAWA & CINA & 10 & $R$ & 9 & $\mathrm{R}$ & 7 & $R$ & 26 & $\mathrm{R}$ \\
\hline 26 & JAWA & SUNDA & 12 & $R$ & 13 & $\mathrm{R}$ & 17 & $S$ & 42 & $\mathrm{R}$ \\
\hline 27 & JAWA & BATAK & 16 & $\mathrm{~S}$ & 18 & $S$ & 11 & $R$ & 45 & $\mathrm{R}$ \\
\hline 28 & BETAWI & AMERIKA & 10 & $\mathrm{R}$ & 17 & $S$ & 12 & $\mathrm{R}$ & 39 & $\mathrm{R}$ \\
\hline 29 & BETAWI & SUNDA & 12 & $R$ & 17 & $S$ & 15 & $\mathrm{R}$ & 44 & $R$ \\
\hline 30 & JAWA & SUNDA & 10 & $\mathrm{R}$ & 15 & $\mathrm{R}$ & 14 & $\mathrm{R}$ & 39 & $\mathrm{R}$ \\
\hline 31 & SUNDA & JAWA & 10 & $R$ & 14 & $\mathrm{R}$ & 14 & $\mathrm{R}$ & 38 & $\mathrm{R}$ \\
\hline 32 & JAWA & ARAB & 10 & $\mathrm{R}$ & 10 & $\mathrm{R}$ & 9 & $\mathrm{R}$ & 29 & $\mathrm{R}$ \\
\hline 33 & JAWA & SUNDA & 12 & $R$ & 11 & $\mathrm{R}$ & 22 & $S$ & 45 & $\mathrm{R}$ \\
\hline 34 & JAWA & SUNDA & 9 & $R$ & 14 & $\mathrm{R}$ & 15 & $\mathrm{R}$ & 38 & $\mathrm{R}$ \\
\hline 35 & $\begin{array}{l}\text { JAWA - } \\
\text { MINANG }\end{array}$ & BETAWI & 12 & $\mathrm{R}$ & 14 & $\mathrm{R}$ & 13 & $\mathrm{R}$ & 39 & $\mathrm{R}$ \\
\hline 36 & SUMATERA & BALI & 7 & $\mathrm{R}$ & 9 & $\mathrm{R}$ & 12 & $\mathrm{R}$ & 28 & $\mathrm{R}$ \\
\hline 38 & JAWA & CINA & 18 & $S$ & 16 & $\mathrm{R}$ & 11 & $\mathrm{R}$ & 45 & $\mathrm{R}$ \\
\hline 37 & SUNDA & BETAWI & 17 & $S$ & 18 & $S$ & 11 & $R$ & 46 & $\mathrm{~S}$ \\
\hline
\end{tabular}

Kategori sikap etnis adalah sebagai berikut:
$73-100$
= Tinggi
$46-72$
$=$ Sedang
$20-45$
$=$ Rendah 
Tabel 2 Taraf Prasangka Sosial

\begin{tabular}{|l|l|l|}
\hline No & Komponen sikap & Taraf sikap \\
\hline 1. & Sifat pribadi & $\begin{array}{l}\text { Tinggi }=1 \\
\text { Sedang }=20 \\
\text { Rendah }=17\end{array}$ \\
\hline 2. & Sifat sosial & $\begin{array}{l}\text { Sedang }=19 \\
\text { Rendah }=19\end{array}$ \\
\hline 3. & Sifat kerja & $\begin{array}{l}\text { Sedang }=14 \\
\text { Rendah }=28\end{array}$ \\
\hline 4. & Sikap etnis: & $\begin{array}{l}\text { Sedang }=18 \\
\text { Rendah }=20\end{array}$ \\
\hline
\end{tabular}

b. Obyek Prasangka Sosial

Berdasarkan obyeknya, prasangka sosial ditujukan kepada individu dari etnis yang berbeda. Umumnya obyek prasangka adalah individu yang sering berhubungan dengan, tetapi juga terdapat individu dari kelompok yang tidak berhubungan langsung. Obyek sikap terbanyak adalah berasal dari etnis Betawi dan Sunda, yang paling sedikit adalah Sulawesi, Amerika dan Arab. Untuk etnis yang benar-benar asing adalah Amerika, karena obyek sikap tidak berhubungan secara langsung, sementara untuk etnis Arab dan Cina bukan orang yang benar-benar berada di negara asalnya, tetapi Arab dan Cina yang berada di sekitar lingkungan dari subyek. Secara umum, gambaran obyek sikap dari prasangka sosial adalah sebagai berikut:

Tabel 3. Objek Sikap

\begin{tabular}{|c|l|c|}
\hline No & Objek sikap & Jumlah \\
\hline 1 & Batak & 4 \\
\hline 2 & Betawi & 12 \\
\hline 3 & Bali & 3 \\
\hline 4 & Cina & 3 \\
\hline 5 & Sulawesi & 1 \\
\hline 6 & Sunda & 11 \\
\hline 7 & Amerika & 1 \\
\hline 8 & Arab & 1 \\
\hline 9 & Jawa & 2 \\
\hline & & 38 \\
\hline
\end{tabular}

Dapat disimpulkan bahwa penyebab dari prasangka sosial yang berkembang di sekolah banyak disebabkan oleh sifat pribadi dan sifat sosial. Dengan objek sikap dari etnis yang dianggap memiliki banyak perbedaan dalam budaya. 


\section{Pembahasan}

Hasil penelitian mengenai prasangka sosial menunjukan bahwa prasangka sosial di sekolah masih ada. Hal ini menunjukkan bahwa perbedaan akan menimbulkan prasangka. Secara umum responden memiliki sikap prasangka terhadap sifat pribadi berada pada taraf sedang dan rendah, tetapi didapatkan juga satu responden yang berada pada taraf yang tinggi. Demikian juga dengan prasangka terhadap sifat sosial, responden memiliki prasangka pada taraf sedang dan rendah dengan komposisi yang berimbang. Sementara untuk sifat kerja, kebanyakan peserta memiliki prasangka yang rendah. Kesimpulan umum didapatkan bahwa, prasangka terhadap sikap etnis kebanyakan peserta memiliki prasangka pada taraf rendah dan sebagian pada taraf sedang.

Taraf prasangka sosial seperti disebabkan oleh berbagai faktor, yaitu: karena adanya proses kategorisasi dalam diri individu. Kategorisasi tersebut mencakup etnisitas dan kecenderungan menjaga jarak sosial dengan orang-orang yang dianggap out-group. Dapat dipastikan bahwa obyek prasangka adalah kelompok etnis yang memiliki budaya yang berbeda.

Faktor lain penyebab terjadinya prasangka adalah hasil proses belajar (social learning theory). Menurut teori ini, prasangka pada dasarnya dipelajari oleh individu dari perilaku individu lain di sekitarnya dan dari norma-norma sosial yang terdapat di dalam masyarakat kebudayaannya. Dalam penelitian ini, obyek prasangka adalah, kelompok etnis yang dalam budaya tertentu dianggap memiliki perbedaan tertentu. Responden dari etnis Jawa umumnya memiliki obyek prasangka pada kelompok etnis Betawi ataupun Sunda.

Apabila menurut teori norma kelompok yang dikemukakan oleh Sherif dan Sherif (dalam Crandall dkk, 2002) menggambarkan tentang perkembangan prasangka yang dikaitkan dengan norma sosial kelompok dan adanya tekanan agar individu dapat conform terhadap norma kelompok tersebut. Menurut teori ini, sikap, nilai-nilai, keyakinan dan prasangka merupakan bagian dari proses sosialisasi (Sherif; dalam Crandall dkk, 2002). Menurut Sherif (dalam Crandall dkk, 2002) sikap, nilai-nilai dan prasangka bukan merupakan hasil dari pilihan-pilihan individu yang diperoleh selama hidupnya. Hal tersebut merupakan hasil kontak dengan anggota dari kelompok lain, yang kemudian distandardisasikan lalu diinternalisasikan menjadi nilai-nilai kelompoknya. Kepatuhan seseorang pada nilai-nilai in-groupnya akan mengarahkan pada munculnya prasangka. 
$52 \mid \begin{aligned} & \text { JURNAL ILMIAH MIMBAR DEMOKRASI } \\ & \text { VOLUME 12, NOMOR 2, APRIL } 2013\end{aligned}$

Prasangka menyebabkan seseorang enggan bertemu dengan yang obyek prasangka. Penghindaran itu beraneka macam, misalnya menghindari jalan-jalan yang banyak digunakan oleh etnis lain, tidak mau bekerja sama dengan etnis lain, selalu menutup pintu rumah, tidak mau berbicara dengan etnis lain, menghindari terjadinya pernikahan dengan etnis lain, dan sebagainya. Adanya penghindaran itu menyebabkan terjadinya komunikasi yang tidak lancar. Akibatnya, tidak pernah terjalin keakraban sosial antar etnik. Seterusnya, antara etnis-etnis yang berbeda jadi kehilangan kesempatan untuk bergaul secara akrab halmana merupakan jalan yang efektif untuk mengurangi prasangka. Maka, wujudlah penghindaran terhadap obyek prasangka sehingga semakin meneguhkan prasangka yang ada.

Prasangka sosial yang tinggi akan memberikan dampak kepada kemunculan konflik. Tanpa upaya yang tepat dalam mengelola perbedaan, prasangka akan sangat mudah membawa kepada konflik. Terutama apabila ditunjang dengan keinginan untuk berkompetisi, meskipun kadangkala merupakan kompetisi semu. Menurut teori realistic group conflict, kompetisi akan menimbulkan permusuhan serta penilaian yang negatif terhadap kelompok lain (outgroup).

\section{KESIMPULAN DAN SARAN}

\section{Kesimpulan}

Prasangka sosial pada masyarakat multietnis menjadi sesuatu yang sangat umum. Perbedaan yang luas dan jarak sosial yang jauh menjadi penyebab dari prasangka sosial yang selanjutnya dapat berdampak kepada konflik. Indonesia secara alamiah adalah negara yang sangat berbhineka, tidak hanya dari etnisitas, tetapi juga budaya secara umum. Dengan demikian banyaknya perbedaan akan memberikan dampak-dampak, baik secara positif maupun negatif. Dampak positif tentunya memberikan keuntungan berupa kekayaan budaya yang luar biasa, tetapi sisi lain memberikan dampak negatif, berupa adanya prasangka sosial. Jarak sosial yang jauh dan pemahaman yang rendah terhadap warga dari etnis yang berbeda akan membuat kemunculan konflik menjadi mudah terjadi. Untuk itu adanya cara untuk menjadikan perbedaan menjadi suatu kekuatan merupakan hal yang sangat penting untuk dapat dikembangkan di Indonesia.

Berdasarkan penelitian yang dilakukan pada prasangka sosial, yang meliputi sifat pribadi, sifat sosial, sifat pekerjaan dan sikap etnis didapatkan bahwa, secara umum prasangka sosial pada pelajar di Indonesia berada pada tahap sedang. Dapat disimpulkan pula bahwa prasangka terhadap sifat pribadi adalah 
penyebab utama tingginya prasangka terhadap obyek prasangka. Hal ini berarati bahwa pada kelompok pelajar prasangkaprasangka dengan latar belakang etnis masih merupakan sesuatu yang biasa. Meskipun tidak pada taraf yang tinggi, tetapi kondisi ini sudah selayaknya untuk diperhatikan.

Prasangka sosial akan mudah untuk mendorong ke arah terjadinya konflik. Untuk itu, perlu dikembangkan suatu model pembelajaran yang dapat meredam dan bahkan kalau mungkin untuk menghilangkan adanya konflik-konflik terutama yang berbasis etnisitas.

\section{DAFTAR PUSTAKA}

Allport, Gordon. 1954. The Nature of Prejudice. New York: Doubleday Books.

Arikunto, S. 1992. Prosedur Penelitian, Suatu Pendekatan Praktek. Yogyakarta: Rineka Cipta.

Banks A. James. 1997. Educating Citizens in a Multicultural Society. New York: Teachers College Columbia University.

Eriyanto, et.al. 2004. Media dan Konflik Etnis. Jakarta: Penerbit Institut Studi Arus Informasi bekerja sama dengan Media Development Loan Fund.

Grim, Patrick, Selinger, Evan, Braynen,William, Rosenberger, Robert, Au, Randy, Louie, Nancy, and Connolly, John. 2005. "Modeling Prejudice Reduction: Spatialized
Game Theory and the Contact Hypothesis". Public Affairs Qurterly Volume 19, Number 2, April.

Heryanto, Ariel dan Mandal, Sumit K. 2004. Menggugat Otoriterisme di Asia Tenggara. Jakarta: KPG.

Jalal, Fasli dan Supriadi, Dedi. 2001. Reformasi Pendidikan dalam Konteks Otonomi Daerah. Yogyakarta: Adicita Karya Nusa.

Kasiyan. 2008. Manipulasi dan Dehumanisasi Perempuan dalam Iklan. Yogyakarta: Ombak.

Kerlinger, F. N. 1986. Foundations of Behavioral Research, 3rd ed. The US: Holt, Rinehart and Winston.

Kleden, Ignas. 2001. Menulis Politik: Indonesia Sebagai Utopia, Jakarta: Kompas.

Leistyna, Pepi. 2002. Defining and designing Multiculturalism. One School System's Efforts. New York. State University of New York Press.

Lillis, Jason dan Hayes, Steven C. 2007. "Applying Acceptance, Mindfulness, and Values to the Reduction of Prejudice: A Pilot Study". Behavior Modification Volume 31 Number 4 July. London: Sage.

LIPI (Lembaga Ilmu Pengetahuan Indonesia). 2001. Kebijakan Kebudayaan Pada Masa Orde Baru. Jakarta: LIPI.

Madjid, Nurcholish. 2004. Indonesia Kita. Jakarta: Penerbit Universitas Paramadina.

Nadapdap, Amir dkk. 2003.Jurnalisme Anti Toleransi? Rasialisme dalam Pemberitaan Pers. Medan: KIPPAS dan Bina Insani. 
$54 \quad \begin{aligned} & \text { JURNAL ILMIAH MIMBAR DEMOKRASI } \\ & \text { VOLUME 12, NOMOR 2, APRIL } 2013\end{aligned}$

Nazaruddin, Muzayin. 2008. Islam Representation in Religious Electronic Cinemas in Indonesia. Yogyakarta: UII.

Pabottingi, Mochtar. 1999. Suara Waktu. Jakarta: Penerbit Erlangga.

Pelly, Usman. 2004. "Away from melting Pot: The Rise of Chinese School in Medan City". Dalam Jurnal Antropologi Indonesia. Depok: Jurnal Antropologi Indonesia.

Priyono, A.E, Prasetyo, Stanley Adi, Tornquist, Olle. 2003. Gerakan Demokrasi di Indonesia Pasca Soeharto. Jakarta: Demos.

Sarwono, Sarlito Wirawan. 2006. Psikologi Prasangka Orang Indonesia: Kumpulan Studi Empirik Prasangka dalam Berbagai Aspek Kehidupan Orang Indonesia. Jakarta: PT Raja Grafindo Persada, Rajawali Pers.
Slavin, Robert E.. 2001. "Cooperative Learning and Intergroup Relations." Dalam Handbook of Research on Multicultural Education. James A. Banks and Cherry A. McGee Banks (Ed.). San Francisco: Jossey-Bass.

Sudibyo, Agus, Hamad, Ibnu, dan Qodari, Muhammad. 2001. Kabar-kabar Kebencian: Prasangka Agama di Media Massa. Jakarta: ISAI.

Tilaar. H.A.R. 2007. Mengindonesia: Etnisitas dan Identitas Bangsa Indonesia. Jakarta: Rineka Cipta.

Tilaar, H.A.R. 2003. Kekuasaan dan Pendidikan: Suatu Tinjauan dari Perspektif Studi Kultural, Magelang: Indonesia Tera.

Therik, Tom. 2004. "The Notion of Context in Multicultural Education: A Nusa Tenggara Timur Case". Dalam Jurnal Antropologi Indonesia. Depok: Jurnal Antropologi Indonesia 